\title{
Influence of the Chelation Process on the Stability of Organic Trace Mineral Supplements Used in Animal Nutrition
}

\author{
Laurann Byrne $^{1, * \mathbb{D}}$, Michael J. Hynes ${ }^{2}$, Cathal D. Connolly ${ }^{1}$ and Richard A. Murphy ${ }^{1} \mathbb{D}$ \\ 1 Alltech Bioscience Centre, Summerhill Road, Dunboyne, A86 X006 Co. Meath, Ireland; \\ cconnolly@alltech.com (C.D.C.); rmurphy@alltech.com (R.A.M.) \\ 2 School of Chemistry, National University of Ireland, H91 TK33 Galway, Ireland; reachforhynes@eircom.net \\ * Correspondence: lbyrne@alltech.com
}

check for updates

Citation: Byrne, L.; Hynes, M.J.; Connolly, C.D.; Murphy, R.A.

Influence of the Chelation Process on the Stability of Organic Trace Mineral Supplements Used in Animal Nutrition. Animals 2021, 11, 1730. https://doi.org/10.3390/ani11061730

Academic Editor: Stephanie Hansen

Received: 22 April 2021

Accepted: 8 June 2021

Published: 10 June 2021

Publisher's Note: MDPI stays neutral with regard to jurisdictional claims in published maps and institutional affiliations.

Copyright: (c) 2021 by the authors. Licensee MDPI, Basel, Switzerland. This article is an open access article distributed under the terms and conditions of the Creative Commons Attribution (CC BY) license (https:// creativecommons.org/licenses/by/ $4.0 /)$.
Simple Summary: Organic trace minerals (OTMs) are recognised globally as being a more bioavailable source of mineral than their inorganic counterparts. Whilst there are many forms of mineral products available for use in animal nutrition, these have unfortunately been generically entitled "organic trace minerals" by virtue of the fact that the trace elements in question are complexed or otherwise associated with organic molecules. The process of chelating transition elements such as copper, iron or zinc, for instance, typically involves reacting inorganic mineral salts with suitable bonding groups, such as a peptides or amino acids, during which the mineral becomes part of a biologically stable structure. Numerous production processes have been developed, ranging from highly specific and controlled reaction processes to more involved chemical synthesis routes. The production process used determines the product's efficacy. Given the vastly different products that exist in the marketplace, the importance of understanding the physical and chemical differences between them cannot be overstated, and as such, manufacturing processes that affect the $\mathrm{pH}$ stability and functionality of the finished products were assessed in this work. The results showed that in the case of proteinate type products, the hydrolysis procedure used to generate the chelating peptides had a significant impact on proteinate $\mathrm{pH}$ stability, a key determinant of the product's performance in the animal.

Abstract: The effect of the chelation process on the $\mathrm{pH}$-dependent stability of organic trace minerals (OTMs) used as mineral supplements in animal nutrition was assessed using analytical techniques such as potentiometry, Fourier Transform Infrared Spectroscopy (FTIRS) and amino acid profiling. The aim was to understand the influence and relative importance of the manufacturing conditions on mineral chelation and the subsequent $\mathrm{pH}$ stability of OTMs. A selection of OTMs were assessed over a wide $\mathrm{pH}$ range to account for the typical environmental changes encountered in the gastrointestinal (GI) tract. In the case of proteinate type products, the potentiometric assessment of free mineral concentration indicated that the hydrolysis procedure used to generate the chelating peptides was the major influencer of the $\mathrm{pH}$ stability of the products. Many products are available under the umbrella term "OTMs", including amino acid complexes, amino acid chelates, polysaccharide complexes and proteinates. Significant differences in the $\mathrm{pH}$-dependent stability of a range of commercially available OTMs were observed.

Keywords: proteinates; organic trace minerals (OTMs); enzyme hydrolysis; acidic stability; mineral absorption

\section{Introduction}

The importance of dietary supplementation of trace minerals in animal feed is well known and various forms of both organic and inorganic products are commercially available. Organic trace minerals (OTMs) such as proteinates are known to be more bioavailable than inorganic trace mineral forms, thereby allowing more mineral to be absorbed and 
increasing the mineral status within the animal [1-12]. The strength of the bonds between the ligands and the mineral on the formation of a mineral chelate can prevent dissociation as it passes through the digestive system and enhance mineral bioavailability. In addition to demonstrated active uptake mechanisms [13,14], it is understood that organic trace minerals dissociate from their carrier groups in the intestinal lumen and are then absorbed into enterocytes lining the gastrointestinal tract. Reported differences in the bioavailability of organic minerals have also been attributed to the differences in dissociation rates of the mineral from the organic group to which they are bound, or to differences in mineral-chelate solubility [14].

Organic trace mineral characteristics vary between products and are determined by the type of ligands used to bond with the mineral. These ligands are usually amino acids, peptides, polysaccharides and organic acids. Although a selection of commercially available OTMs were assessed, the primary focus of this work was on proteinate products. These are produced by partially hydrolysing a protein source using either acid and/or enzymatic procedures. This results in the formation of a hydrolysate containing a mixture of amino acid and peptide ligands of varying chain length and molecular size, depending on the degree of hydrolysis. Under the appropriate conditions, the reaction of a soluble mineral salt with such a hydrolysate results in the formation of a range of mineral-ligand complexes or chelates, where the mineral is covalently bound to the ligand.

Mineral-organic ligand combinations can result in the production of one of several classes of OTMs. The Association of American Feed Control Officials (AAFCO) has classified them into groups (metal-amino acid chelates, metal-amino acid complexes, specific metal-amino acid complexes, metal proteinates and polysaccharide metal complexes), and the mineral binding properties vary greatly between them [15]. Some of these definitions and classifications have led to confusion in the industry. For example, the AAFCO defines an amino acid metal chelate as "the product resulting from the reaction of a metal ion from a soluble metal salt with amino acids, with a mole ratio of one mole of metal to one to three (preferably two) moles of amino acids to form coordinate covalent bonds". Since this definition does not consider the actual binding in the complex, it is possible that a complex considered a chelate by animal nutritionists might not be considered as such by a chemist.

In the case of mineral proteinates, which are the subject of this work, the efficiency of the hydrolysis procedure and the choice of enzyme are only two of many factors that can affect the stability of the final product. An effective hydrolysis procedure is essential to mineral-proteinate production as it cleaves the peptide bonds in the protein source, thereby providing soluble amino acids and small peptides to which the mineral ion can bind. The extent of hydrolysis varies depending on the enzyme used and hydrolysis conditions such as $\mathrm{pH}$, temperature, time, the enzyme-to-substrate ratio and the solid-to-liquid ratio.

\section{Materials and Methods}

All materials used were of ACS grade or higher where appropriate. Chemicals were supplied by Sigma-Aldrich, Tallaght, Ireland. The soy flour protein source was provided by Alltech Bioscience Centre, Dunboyne, Co. Meath, Ireland. Enzymes and commercial OTMs were sourced from independent distributors.

\subsection{Protein Source Hydrolysis}

Protein hydrolysates were prepared in the laboratory using a range of commercially available enzymes as described previously [16]. For acidic hydrolyses, the $\mathrm{pH}$ was maintained at $\mathrm{pH} 3.0 \pm 0.2$ and the temperature at $55 \pm 1{ }^{\circ} \mathrm{C}$. Alkaline hydrolyses were carried out at $\mathrm{pH} 8.5 \pm 0.2$ and $55 \pm 1{ }^{\circ} \mathrm{C}$. $\mathrm{pH}$ adjustments were carried out using sodium hydroxide $(4 \mathrm{M} \mathrm{NaOH})$ or hydrochloric acid (conc. $\mathrm{HCl}$ ) to increase or decrease $\mathrm{pH}$, respectively. Combinations of the selected enzymes were also tested to determine if the hydrolysis procedure was improved with the additional mixtures of ligands produced from the different enzyme's mode of action. 


\subsection{Formation of Mineral Proteinates from Soy Flour Hydrolysate}

The sulphate form of the element was used to prepare batches of mineral proteinates with a final mineral content of $10 \%(w / w)$ when dried. Copper was selected as the element for producing the proteinates as it was possible to measure the free mineral concentration in solution directly by potentiometry. Mineral salt was added to soy hydrolysate $(90 \mathrm{~mL})$ and the contents were mixed for $1 \mathrm{~h}$ at room temperature. The $\mathrm{pH}$ of each proteinate was recorded and the samples were then cooled and frozen at $-70^{\circ} \mathrm{C}$ prior to lyophilisation. The dried powders were homogenised using a pestle and mortar and stored in sterile, high density polyethylene (HDPE) airtight containers. The mineral content of the dried product was confirmed using Inductively Coupled Plasma Optical Emission Spectroscopy (ICP-OES) [17]. Commercial samples of copper (II) proteinates were analysed as received.

\subsection{Amino Acid Profiling}

A free amino acid analysis was carried out at Alta Bioscience, Birmingham, UK, by cation chromatography on a Biotronic LC 5001 automated amino acid analyser, according to a modified method $\left(24 \mathrm{~h}\right.$ at $\left.110^{\circ} \mathrm{C}\right)$ of Spackman et al. [18].

\subsection{Fourier Transform Infrared (FTIR) Spectroscopy}

Fourier Transform Infrared Spectroscopy (FTIRS) spectra were recorded on a PerkinElmer Spectrum 100 FT-IR spectrometer equipped with a Universal Attenuated Total Reflectance (UATR) sampling accessory. All samples were ground using an agate mortar and pestle prior to loading to ensure homogeneity. Samples were pressed onto the UATR crystal at a force of $80 \mathrm{~N}$. Spectra were recorded in the range 1800-650 $\mathrm{cm}^{-1}$ with a resolution of $4 \mathrm{~cm}^{-1}$ and an average of 16 scans/sample was recorded. To avoid cross-contamination, the accessory was washed with deionised water and wiped dry with a non-static laboratory wipe between samples. An air background was collected prior to each analytical run. Analysis was carried out at room temperature. The FTIR spectra were subjected to ATR and automatic baseline correction before further analysis.

\subsection{Potentiometric and Ion-Selective Electrode (ISE) Measurements}

Potentiometric titrations were carried out using a combination of two Orion Star Series $\mathrm{pH}$-meters with a precision of $0.1 \mathrm{mV}$ or 0.001 units of $\mathrm{pH}$. One of the meters monitored $\mathrm{pH}$ using a combination glass electrode and an automatic temperature controller. The second meter measured the electromotive force (EMF) and was connected to a Jenway copper combination ion selective electrode (ISE) with a solid-state crystalline membrane and an integral driTEK reference electrode (Barloworld Scientific Ltd., Stone, UK). Standard calibrations were carried out immediately prior to experimental work. Lyophilised samples $(0.25 \mathrm{~g})$ were prepared for analysis by resuspension in $25 \mathrm{~mL}$ distilled water. Titrations were performed in a $50 \mathrm{~mL}$ double-walled glass vessel. The temperature inside the cell was maintained at $25 \pm 0.1^{\circ} \mathrm{C}$ by water circulation through the vessel. Sodium nitrate $\left(0.1 \mathrm{M} \mathrm{NaNO}_{3}\right)$ was used to maintain a constant ionic strength. Titrations were carried out in triplicate. Measurements above $\mathrm{pH} 8$ were not taken due to mineral solubility concerns as well as it being outside of the recommended working range ( $\mathrm{pH} 3-8)$ of the ISE.

\subsection{Statistical Analysis}

Data were analysed by statistical means using the programs Minitab version 20 (Minitab Ltd., Coventry, UK) and The Unscrambler version 10.5 (Camo Analytics, Oslo, Norway). A one-way analysis of means (ANOM) was used to assess differences between means.

\section{Results and Discussion}

The benefits of incorporating OTMs in feed are widely accepted, but the effectiveness of such products relies on preserving the chemical form of the mineral until it can be absorbed into the bloodstream. A large proportion of bioactive compounds are poorly 
available due to factors such as low permeability and/or solubility within the gut, lack of stability during feed processing (temperature, oxygen, light) and challenges in the gastrointestinal tract such as $\mathrm{pH}$ conditions, the presence of enzymes or unwanted interactions with other nutrients [19-22].

The aim of this work was to determine the effect of protein hydrolysis conditions on the $\mathrm{pH}$-stability of trace mineral proteinates. Enzymes cleave peptide bonds specifically, depending on their modes of action and on their amino acid recognition sequences. Some enzymes are more efficient with respect to generating suitable peptide fragments for chelation with a mineral ion [23-25]. In this work, the soy protein was hydrolysed using a variety of enzymes and enzyme combinations (Table 1). Alkaline and acidic enzymes outlined in Table 1 were investigated individually and in combination. Sequential hydrolyses (Samples 11 and 12, Table 1) were also tested, giving each type of enzyme an opportunity to work separately under optimum conditions as determined previously [16]. Several studies have shown that varying the enzyme type during hydrolysis results in mixtures of ligands with different chemical properties and abilities to chelate minerals [24-31].

Table 1. Enzymes selected for protein hydrolyses.

\begin{tabular}{cc}
\hline Hydrolysate Number & Enzyme Used $^{\mathbf{1}}$ \\
\hline 1 & Cysteine Protease 1 \\
2 & Serine Protease \\
3 & Fungal Protease \\
4 & Cysteine Protease 2 \\
5 & Acidic Fungal Protease \\
6 & Serine Protease + Fungal Protease \\
7 & Serine Protease + Cysteine Protease 1 \\
8 & Serine Protease + Cysteine Protease 2 \\
9 & Serine Protease + Acidic Fungal Protease \\
10 & 1-5-Multi enzyme combination \\
11 & 2+ 5-Alkaline followed by acidic hydrolysis \\
12 & $5+$ 2-Acidic followed by alkaline hydrolysis \\
\hline
\end{tabular}

${ }^{1}$ All enzymes were sourced from independent distributors.

The free amino acid profile of each hydrolysate is shown in Figure 1. There were some differences in the concentrations of individual amino acids across the 12 hydrolysis conditions. However, the overall patterns were consistent, probably due to the raw material being the same in each case. It was not possible to attribute the subtle differences in the free amino acid profile to the hydrolysis conditions so amino acids were grouped into categories based on their side chains (R-group) for subsequent statistical analysis. The groups chosen were acidic $(\mathrm{A})$, basic $(\mathrm{B})$, polar $(\mathrm{P})$, neutral $(\mathrm{N})$ and combinations thereof. Again, no significant differences $(p>0.05)$ were observed with regard to the amino acid categories under different hydrolysis conditions (Table 2). These results indicated that amino acid profiling alone does not allow for differentiation between mineral proteinates prepared from enzyme hydrolysates of soy flour.

FTIR spectroscopy was used to discriminate between the different products formed from the mineral proteinates created from the 12 individual soy hydrolysates (Figure 2). Differences were observed in the fingerprint region of these spectra, indicating that the hydrolysis procedure had an effect on the presence of certain functional groups, which, in turn, could have an impact on the ligand mixture's ability to interact with the transition metal ion. For example, carboxylic oxygen and amino nitrogen atoms are involved in the formation of mineral-ligand bonds, so band shifts in these regions should accompany such interactions [32]. These observations agree with previous work on the quantitative analysis of the bound mineral in copper proteinates using ATR-FTIR and powder X-ray diffraction (PXRD) [33].

A potentiometric analysis was used to measure the concentration of free (unbound) copper in aqueous preparations of the test samples. The scatter plot in Figure 3 shows the 
initial bound copper in the laboratory-manufactured proteinates relative to the product $\mathrm{pH}$. The results suggest that there are $\mathrm{pH}$-independent differences in mineral-binding abilities of the hydrolysates. Bound copper concentrations in the test proteinates varied between a low of $14.75 \%$ (Hydrolysis 2) and a high of $51.41 \%$ (Hydrolysis 8 ). Hydrolysates from multiple enzymes had higher bound copper levels (Figure 3), a trend that was observed when the $\mathrm{pH}$ of these proteinates was lowered to $\mathrm{pH} 3$ for the potentiometric titration (Figure 4).

Due to the differences in the $\mathrm{pH}$ of each of the test proteinate soluble fractions, each was adjusted to $\mathrm{pH} 3$ prior to potentiometric titration in order to standardise the starting point while staying within the operating range of the ion selective electrode. During the titration, aliquots of base $(0.1 \mathrm{M} \mathrm{NaOH})$ were added incrementally to allow for the measurement of free $\mathrm{Cu}^{2+}$ concentrations up to $\mathrm{pH}$ 8. This allowed for the bound copper $(\%)$ to be calculated across the $\mathrm{pH}$ range from 3 to 8 (Figure 4 ).

25

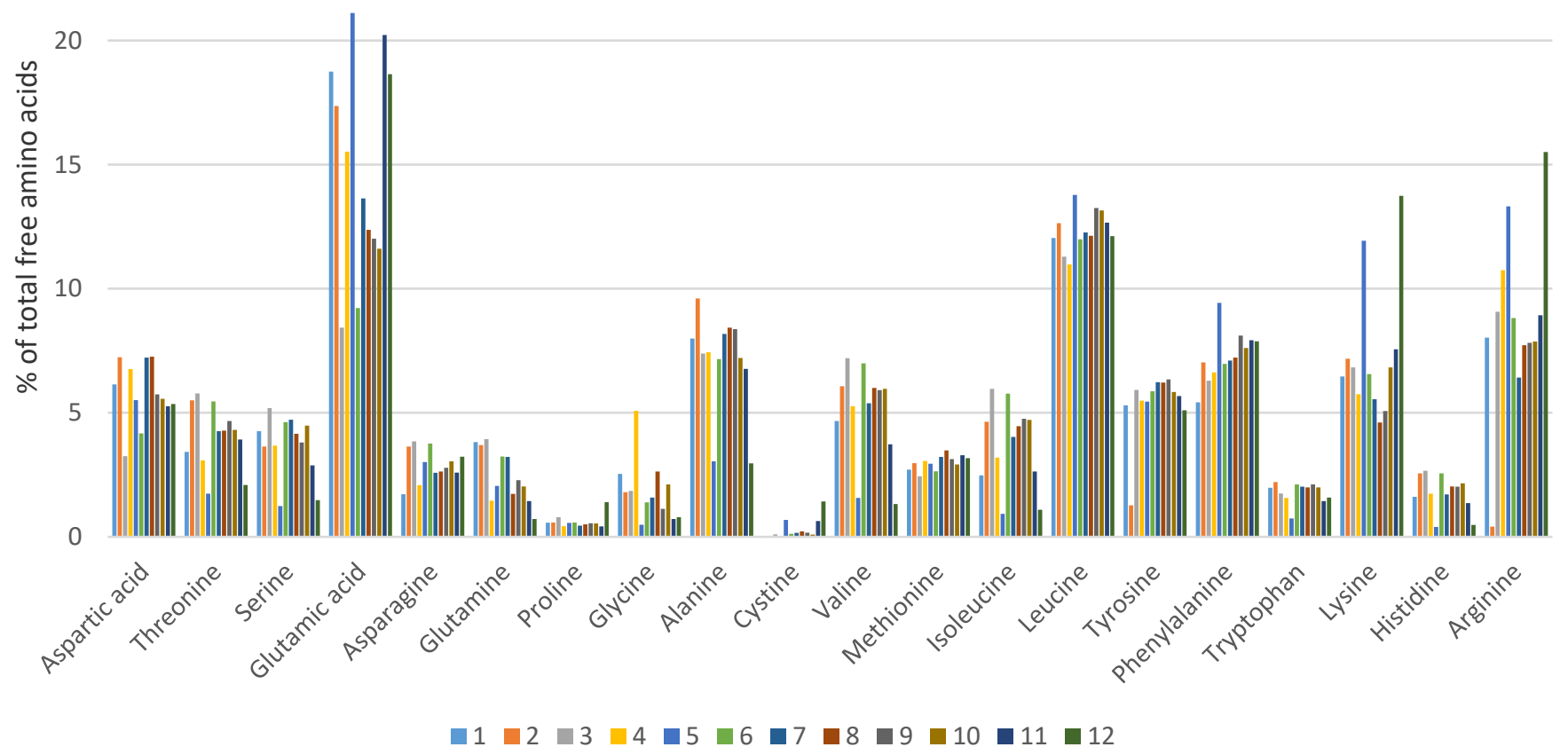

Figure 1. Free amino acid profiles of soy protein following enzymatic hydrolysis under different conditions. 1-12 refer to the individual hydrolysates outlined in Table 1.

Table 2. Descriptive statistics for amino acid group data and different hydrolysis procedures using Minitab.

\begin{tabular}{|c|c|c|c|c|c|c|c|c|c|c|}
\hline Variable & AA Group ${ }^{1}$ & $\mathbf{N}$ & Mean & SE Mean & StDev & Minimum & Q1 & Median & Q3 & Maximum \\
\hline \multirow[t]{10}{*}{$\%$} & $\mathrm{~A}+\mathrm{N}$ & 12 & 64.45 & 1.82 & 6.29 & 56.28 & 59.27 & 65.07 & 66.33 & 78.28 \\
\hline & $A+P$ & 12 & 39.488 & 0.748 & 2.590 & 36.452 & 37.163 & 38.470 & 42.278 & 43.411 \\
\hline & Acidic & 12 & 20.70 & 1.41 & 4.87 & 11.68 & 17.32 & 21.57 & 24.82 & 26.62 \\
\hline & $\mathrm{B}+\mathrm{A}$ & 12 & 38.53 & 2.27 & 7.85 & 30.23 & 33.00 & 34.65 & 42.74 & 53.71 \\
\hline & $\mathrm{B}+\mathrm{N}$ & 12 & 61.593 & 0.973 & 3.370 & 57.419 & 58.216 & 61.945 & 63.406 & 69.486 \\
\hline & $\mathrm{B}+\mathrm{P}$ & 12 & 36.63 & 1.32 & 4.57 & 27.90 & 34.19 & 34.97 & 40.72 & 43.77 \\
\hline & Basic & 12 & 17.84 & 1.52 & 5.26 & 10.15 & 14.50 & 17.36 & 18.48 & 29.72 \\
\hline & Neutral & 12 & 43.76 & 1.73 & 5.99 & 32.29 & 40.59 & 45.28 & 47.21 & 53.39 \\
\hline & $\mathrm{P}+\mathrm{N}$ & 12 & 62.55 & 2.41 & 8.35 & 46.34 & 57.39 & 65.68 & 68.34 & 71.91 \\
\hline & Polar & 12 & 18.792 & 0.950 & 3.293 & 14.051 & 16.133 & 18.876 & 20.890 & 24.775 \\
\hline
\end{tabular}

${ }^{1}$ For the amino acid (AA) groupings outlined, $\mathrm{A}=$ Acidic, $\mathrm{B}=$ Basic, $\mathrm{N}=$ Neutral and $\mathrm{P}=$ Polar. 


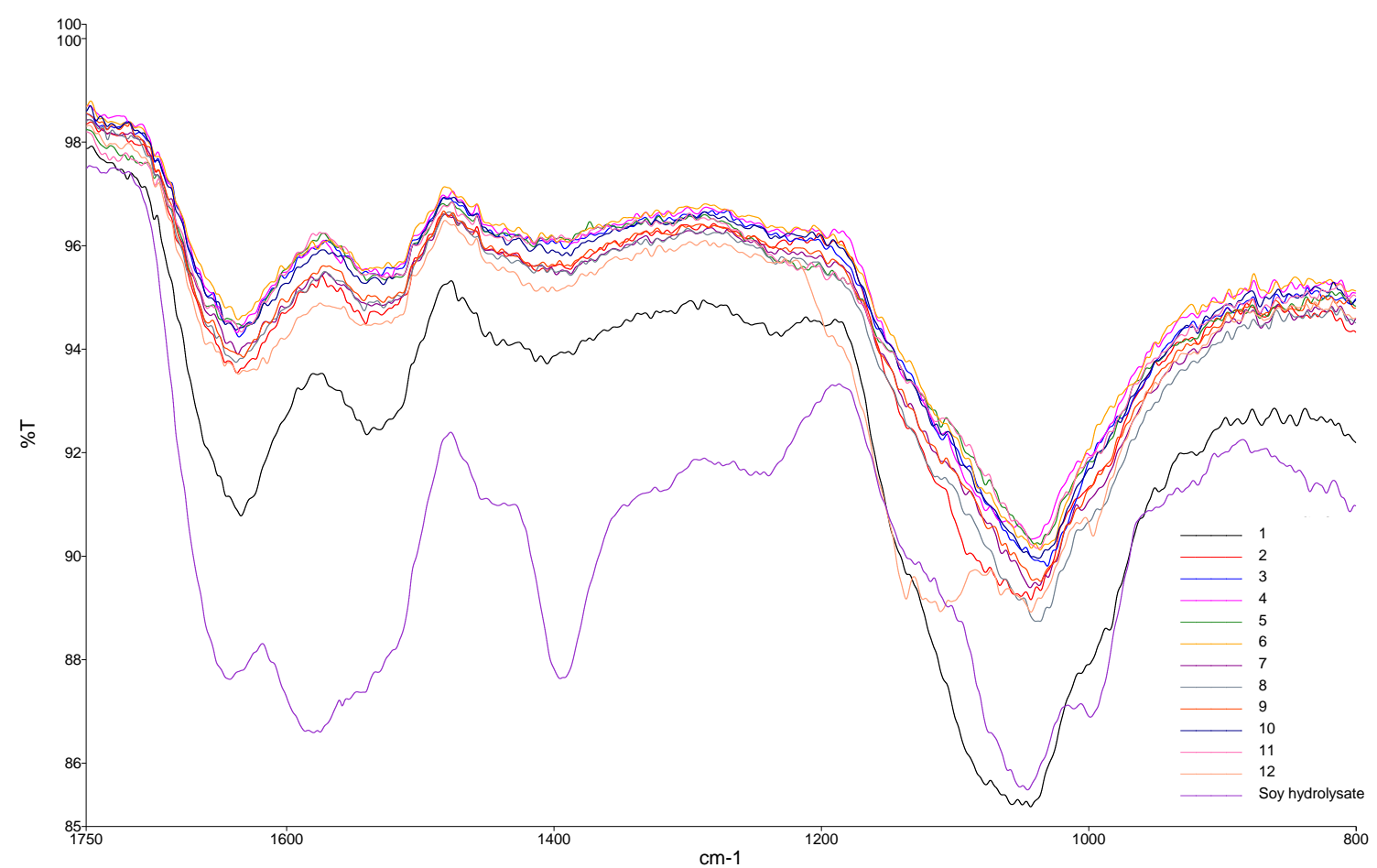

Figure 2. FTIR spectral overlays of copper proteinates formed from a variety of enzymatic hydrolysis procedures. 1-12 refer to the individual hydrolysates outlined in Table 1.

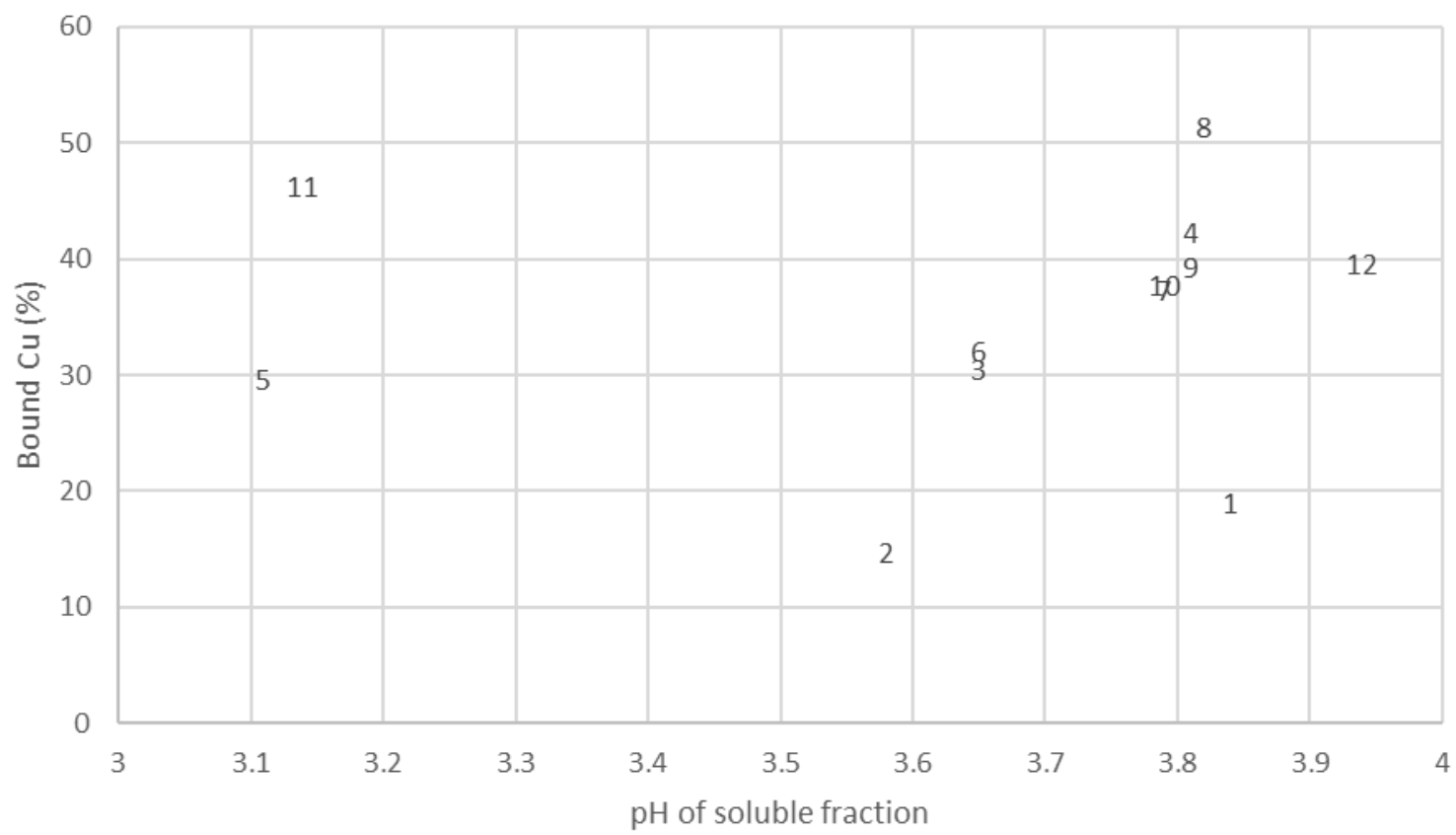

Figure 3. Scatter plot of initial $\mathrm{pH}$ and corresponding bound $\mathrm{Cu}(\%)$ for mineral proteinates. 1-12 refer to the individual hydrolysates outlined in Table 1.

It is apparent from the data in Figure 4 that there are distinct variations in the stability of the various laboratory-manufactured proteinates across the $\mathrm{pH}$ range studied. Hydrolysates formed through the use of multiple enzymes appear to have the highest mineral binding ability as there is less free $\mathrm{Cu}^{2+}$ detected by the ISE over the course of the titration. This correlates with the scatter plot results of initial $\mathrm{pH}$ values and percentage mineral bound in the 12 proteinates (Figure 3). 


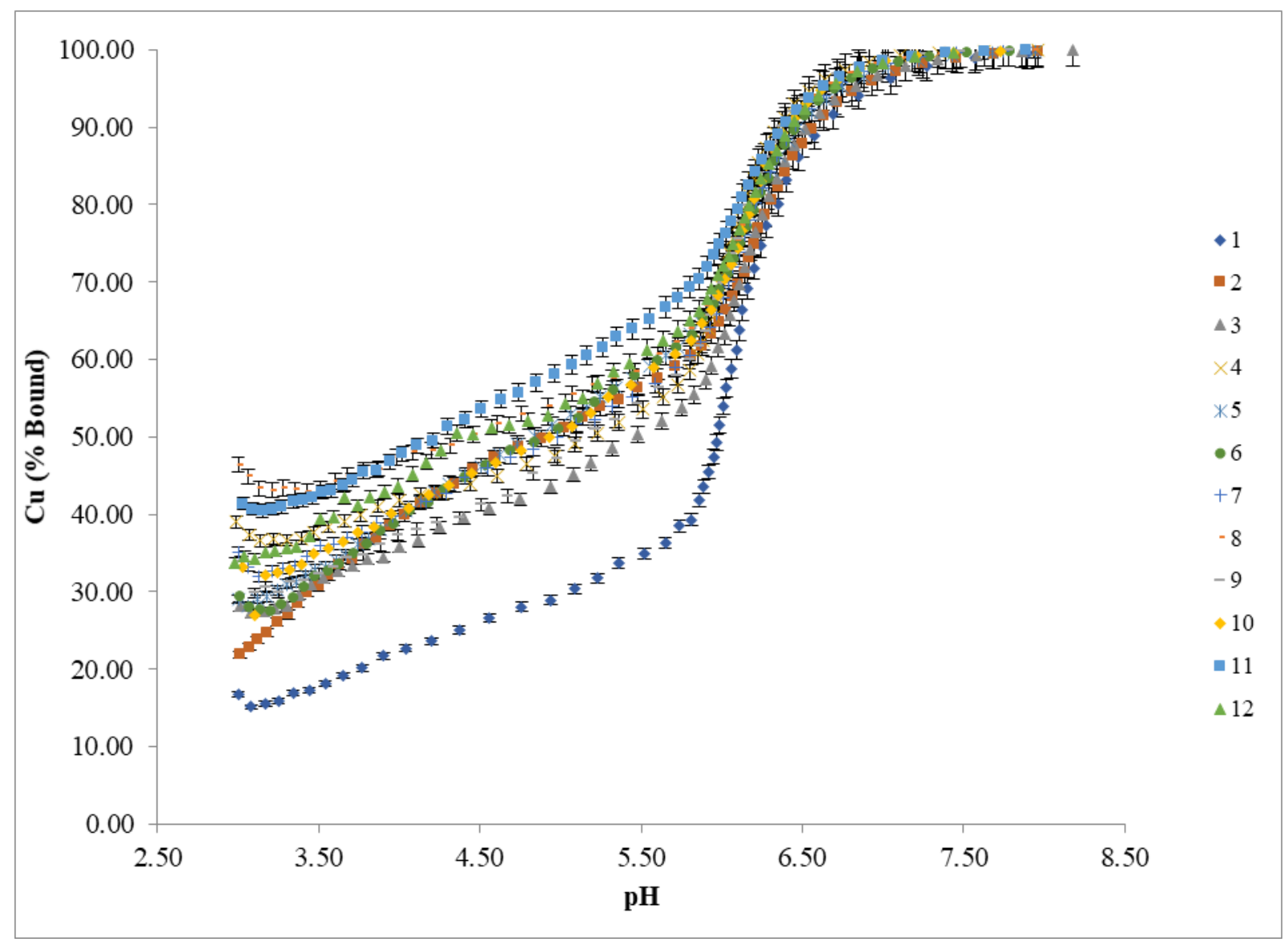

Figure 4. ISE titrations $(n=3)$ of bound $\mathrm{Cu}$ in proteinates containing $10 \%(w / w) \mathrm{Cu}$. 1-12 refer to the individual hydrolysates outlined in Table 1.

Based on the results of the ISE titrations, the free amino acid profiling results obtained for each enzymatic hydrolysis (Figure 1) were further assessed to determine if any correlation existed between the free amino acid groups and the percentage of bound $\mathrm{Cu}$ in the samples. This enabled assessment on whether the mineral was associated with free amino acids produced from the various enzymatic hydrolyses. The classes of amino acids, and the combinations of classes of amino acids were assessed by a One-way Analysis of Means. Figure 5a,b illustrate the One-way Analysis of Means at $\mathrm{pH} 3$ and $\mathrm{pH} 5$ of the different hydrolysates in relation to the level of bound $\mathrm{Cu}$. The secondary dataset ( $\mathrm{pH} 5$ ) was chosen to reflect the average $\mathrm{pH}$ in the duodenum, which is the main site of absorption of trace minerals. Overall, this data shows no clear correlation between the level of bound copper and/or grouped amino acids. These results reinforce the proposition that mineral binding is not significantly dependent on the level and extent of free amino acids, but it is other protein-derived hydrolysis products (peptides) that play a central role with respect to mineral chelation in proteinates.

Figure 6 shows a main effects plot for bound mineral at $\mathrm{pH} 3$ and $\mathrm{pH} 5$. Results are plotted from low to high in terms of bound $\mathrm{Cu}$ results at each $\mathrm{pH}$. As the $\mathrm{pH}$ is increased from 3 to 5 , there is a general trend towards more bound copper present, however, this does not hold true in all cases, indicating the impact of the hydrolysis procedure itself has a greater effect on the bound mineral. Hydrolysis 8 , which combines both acidic and alkaline enzymes, had the highest bound copper at both $\mathrm{pH}$ values. Reviewing the percentage of each individual amino acid present in this hydrolysis compared to the other eleven (Figure 1), none were present in significantly higher or lower levels that might account for the observed increase in mineral binding. Similarly, no clear benefit was noted with the use of acidic or alkaline enzymes in terms of enhancing mineral binding and no correlation 
between the extent of mineral binding and the use of multi-enzyme hydrolysis procedures was observed.

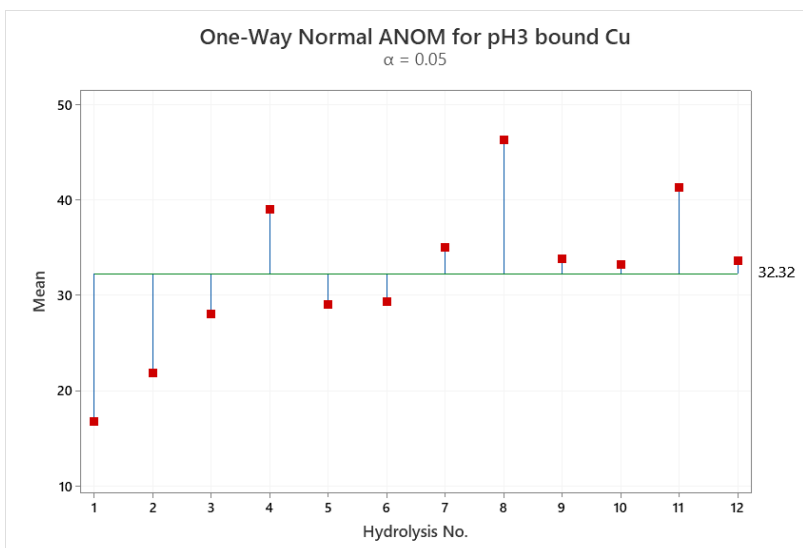

(a)

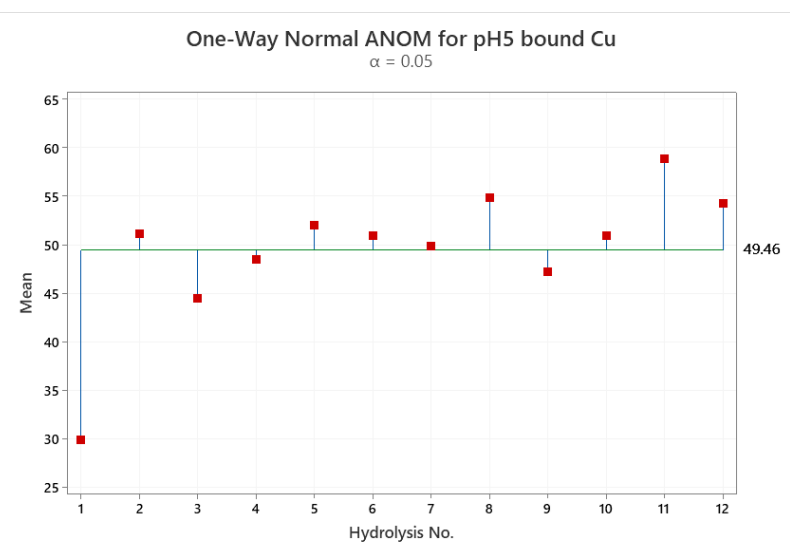

(b)

Figure 5. (a) One-Way Analysis of Means for bound $\mathrm{Cu}$ at $\mathrm{pH}$ 3; (b) One-Way Analysis of Means for bound $\mathrm{Cu}$ at $\mathrm{pH} 5$. 1-12 refer to the individual hydrolysates outlined in Table 1.

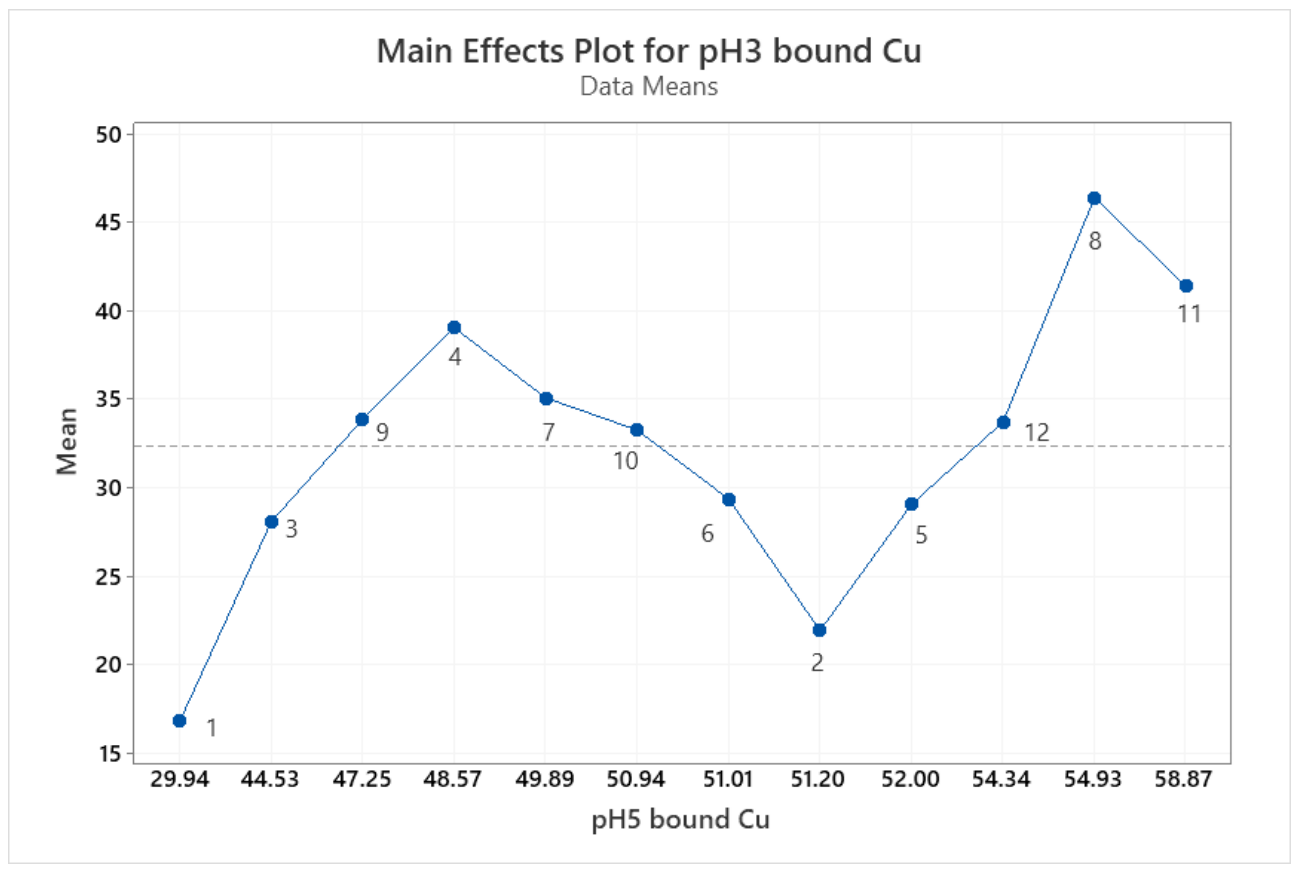

Figure 6. Main effects plot for bound $\mathrm{Cu}$ at $\mathrm{pH} 3$ vs. $\mathrm{pH}$ 5. The values $1-12$ represent the average value obtained from results obtained at $\mathrm{pH} 3$ and $\mathrm{pH} 5$ for the 12 individual hydrolysates in Table 1.

Certain individual amino acids can have greater affinity for $\mathrm{Cu}$ ions under specific conditions and can contribute to mineral binding [34,35]. In this study, the differential ability of proteinates to bind mineral stably appeared not to be dependent on the presence of amino acids either individually or based on their R-group. The enzymatic hydrolysis of protein will result in the release of free amino acids along with short chain peptides, both of which can act as mineral binding ligands. The amino acid configuration in a peptide can significantly influence their ability to interact with trace minerals and consequently affect the overall stability of resultant chelates [25,36-41]. To illustrate this point, Table 3 highlights the stability constants for a number of tripeptides complexed with $\mathrm{Cu}(\mathrm{II})$ under identical physiological conditions. $\log \beta$ refers to the log of the stability constant and the corresponding subscript refers to the metal:ligand ratio. 
Table 3. ML ${ }^{1}$ stability constant values for a selection of tripeptides ${ }^{3}$.

\begin{tabular}{cc}
\hline Tripeptides & $\log \beta_{\mathbf{M L}}{ }^{\mathbf{1 , 2}}$ \\
\hline Gly-Gly-Gly & 5.13 \\
Gly-Gly-His & 7.55 \\
Gly-His-Gly & 9.25 \\
Gly-His-Lys & 16.44 \\
Gly-Gly-Tyr & 10.01 \\
\hline
\end{tabular}

${ }^{1}$ ML refers to the Metal:Ligand ratio; ${ }^{2} \log \beta$ refers to the log of the stability constant and the corresponding subscript refers to the Metal:Ligand ratio. ${ }^{3}$ Values sourced from National Institute of Standards and Technology database [42].

Table 3 shows that the sequence and position of amino acids within a peptide can have a significant impact on stability. The substitution of histidine into the tripeptide Gly-Gly-Gly to yield Gly-Gly-His, for instance, enhances the stability and thus the relative proportion of bound copper. Changing the position of this histidine within the tripeptide sequence (to form Gly-His-Gly, for example) can result in a further increase in the bond strength and, as such, an increase in the proportion of the bound mineral. In practical terms, simple changes in the configuration of amino acids in this tripeptide result in a greater proportion of bound mineral relative to free mineral and ligands. Previous work assessed the effect of the positional substitution of histidine in the tripeptide sequence, in addition to longer chain peptide sequences, and factors such as folding and structural rearrangements (e.g., the formation of fused rings) can also contribute to enhanced stability $[16,43]$. Essentially, proteinate stability can be significantly influenced not only by the type of peptide used, but also the configuration of amino acids in a peptide sequence.

To generate proteinates with effective mineral binding capabilities, the choice of enzyme is important with respect to obtaining a hydrolysate containing peptides with strong potential as ligands for chelation. All enzymatic hydrolysates chosen for this work were capable of binding mineral ions, however little correlation was observed between ability to bind copper and the free amino acid profiles of the individual proteinates. Several studies have shown that strongly coordinating side chain residues in appropriate locations can behave as anchors for the coordination of the amide donors of peptides $[24,25,44-47]$ and will therefore play a much greater role in influencing the ability of proteinates to stably bind mineral.

\section{Potentiometric Titrations of Commercial OTMs}

Commercially available organic trace mineral products were assessed to determine whether or not potentiometric titrations could assist with product differentiation based on their different manufacturing processes. A range of products containing 10.34 to $19.09 \%$ $(w / w) \mathrm{Cu}$ were analysed. Aqueous suspensions of these products had highly variable $\mathrm{pH}$ values, thus reflecting the different procedures used during their manufacture (Figure 7).

Most of the samples were seen to form an insoluble precipitate above $\mathrm{pH} 5.5$, and this phenomenon can be observed as inflections in the curves for these OTMs in Figure 8. When this occurred, it was not possible to continue with the titration.

The commercial samples tested during this study were manufactured using different procedures. Details of these processes were not known by the researchers, other than that the proteinate products were manufactured from hydrolysed plant protein and some form of copper salt. These differences were observed as variability in bound copper concentrations. Previous work assessing a selection of commercially available organic copper products also showed significant differences with bound $\mathrm{Cu}$, varying between 16 and 94\% [48]. 


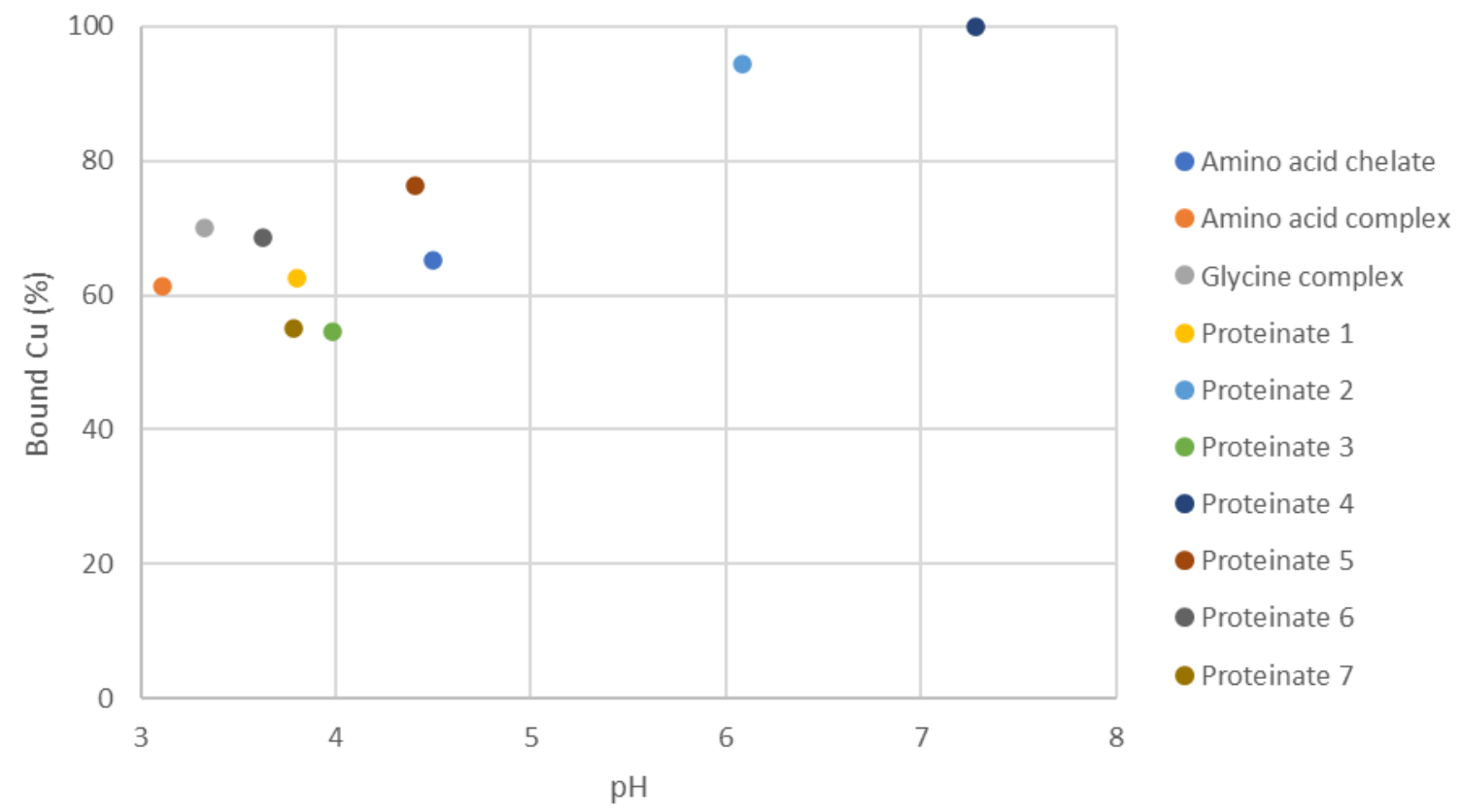

Figure 7. Scatter plot of initial $\mathrm{pH}$ of commercial OTMs and their respective bound copper values.

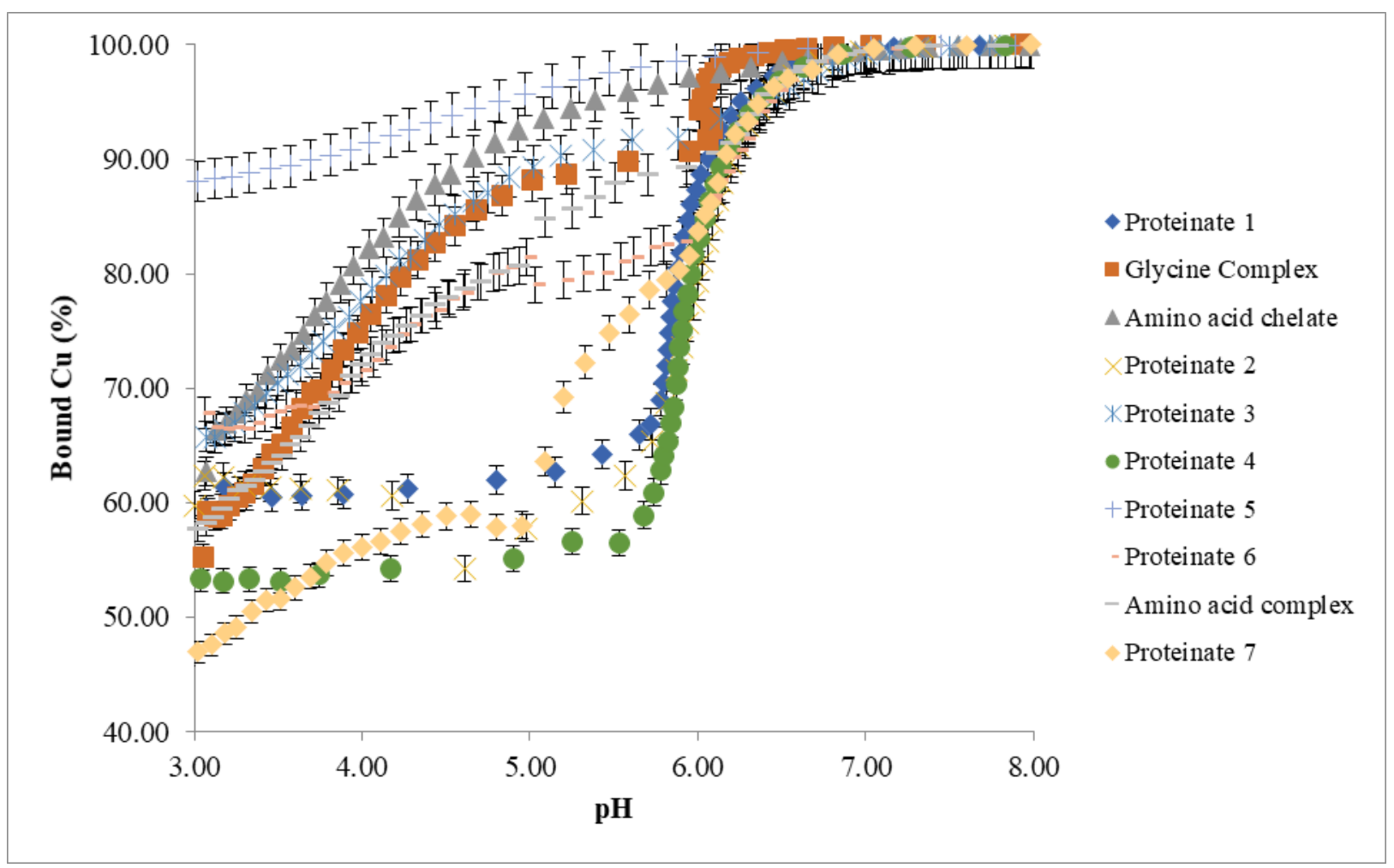

Figure 8. ISE titrations $(n=3)$ of commercial copper OTMs.

\section{Conclusions}

Production processes vary greatly between manufacturers of organic trace minerals and these differences result in products with a wide range of properties, even though they may fall under the same classification and use common terminology. Such products are not expected to be equally effective from a nutritional perspective and the rates of mineral uptake and retention by the animal are likely to differ greatly between them. This work focused on differentiation between mineral (copper) proteinates by directly measuring their 
ability to bind and stabilise the mineral under $\mathrm{pH}$ conditions that may be encountered during digestion. In the case of proteinates that are produced from enzymatically hydrolysed plant protein, it was found that changes to the hydrolysis conditions resulted in products with different concentrations of bound mineral. At first, these changes were thought to be attributable to the free amino acid profile of the hydrolysed protein. However, further investigations showed this not to be the case, and instead, it is the mixture of ligands, which includes not only amino acids but also peptides and soluble polypeptides, that accounts for much of the differences in mineral-binding ability between the products. The analysis of commercially available mineral proteinates allowed for discrimination between them based on their bound mineral concentrations and their responses to $\mathrm{pH}$ changes during potentiometric titrations.

Author Contributions: Conceptualization, L.B. and R.A.M.; methodology, L.B. and R.A.M.; formal analysis, L.B.; investigation, L.B.; data curation, L.B., M.J.H. and C.D.C.; writing-original draft preparation, L.B.; writing-review and editing, L.B., R.A.M., C.D.C. and M.J.H.; visualization, L.B., C.D.C. and R.A.M.; supervision, R.A.M. All authors have read and agreed to the published version of the manuscript.

Funding: This research received no external funding.

Data Availability Statement: Data is contained within the article.

Acknowledgments: Sincere thanks to Alltech Inc. for providing the resources and facilities to complete this work.

Conflicts of Interest: L.B., C.C. and R.M. are employed by Alltech Inc., a manufacture of OTMs. M.J.H. has been involved as an external consultant for Alltech Inc.

\section{References}

1. Parks, F.P.; Harmston, K.J. An assay method from proteinates: Judging organic trace minerals. Feed Manag. 1994, 45, 35-38.

2. Savaram Venkata, R.R.; Bhukya, P.; Raju, M.V.L.N.; Ullengala, R. Effect of Dietary Supplementation of Organic Trace Minerals at Reduced Concentrations on Performance, Bone Mineralization, and Antioxidant Variables in Broiler Chicken Reared in Two Different Seasons in a Tropical Region. Biol. Trace Elem. Res. 2020, 1-8. [CrossRef]

3. Khatun, A.; Chowdhury, S.D.; Roy, B.C.; Dey, B.; Haque, A.; Chandran, B. Comparative effects of inorganic and three forms of organic trace minerals on growth performance, carcass traits, immunity, and profitability of broilers. J. Adv. Vet. Anim. Res. 2019, 6, 66-73. [CrossRef]

4. Wang, G.; Liu, L.J.; Tao, W.J.; Xiao, Z.P.; Pei, X.; Liu, B.J.; Wang, M.Q.; Lin, G.; Ao, T.Y. Effects of replacing inorganic trace minerals with organic trace minerals on the production performance, blood profiles, and antioxidant status of broiler breeders. Poult. Sci. 2019, 98, 2888-2895. [CrossRef] [PubMed]

5. Wang, G.; Liu, L.; Wang, Z.; Pei, X.; Tao, W.; Xiao, Z.; Liu, B.; Wang, M.; Lin, G.; Ao, T. Comparison of Inorganic and Organically Bound. Trace Minerals on Tissue Mineral. Deposition and Fecal Excretion in Broiler Breeders. Biol. Trace Elem. Res. 2019, 189, 224-232.

6. Liu, B.; Xiong, P.; Chen, N.; He, J.; Lin, G.; Xue, Y.; Li, W.; Yu, D. Effects of Replacing of Inorganic Trace Minerals by Organically Bound. Trace Minerals on Growth Performance, Tissue Mineral. Status, and Fecal Mineral. Excretion in Commercial GrowerFinisher Pigs. Biol. Trace Elem. Res. 2016, 173, 316-324.

7. Araújo, C.S.S.; Hermes, R.G.; Bittencourt, L.C.; Silva, C.C.; Araújo, L.F.; Granghelli, C.A.; Pelissari, P.H.; Roque, F.A.; Leite, B.G.S Different dietary trace mineral sources for broiler breeders and their progenies. Poult. Sci. 2019, 98, 4716-4721. [CrossRef]

8. Ward, J.D.; Spears, J.W.; Kegley, E.B. Bioavailability of Copper Proteinate and Copper Carbonate Relative to Copper Sulfate in Cattle. J. Dairy Sci. 1996, 79, 127-132. [CrossRef]

9. Kincaid, R.L.; Blauwiekel, R.M.; Cronrath, J.D. Supplementation of Copper as Copper Sulfate or Copper Proteinate for Growing Calves Fed Forages Containing Molybdenum. J. Dairy Sci. 1986, 69, 160-163. [CrossRef]

10. Wedekind, K.J.; Hortin, A.E.; Baker, D.H. Methodology for assessing zinc bioavailability: Efficacy estimates for zinc-methionine, zinc sulfate, and zinc oxide. J. Anim. Sci. 1992, 70, 178-187. [CrossRef]

11. Predieri, G.; Elviri, L.; Tegoni, M.; Zagnoni, I.; Cinti, E.; Biagi, G.; Ferruzza, S.; Leonardi, G. Metal chelates of 2-hydroxy-4methylthiobutanoic acid in animal feeding: Part 2: Further characterizations, in vitro and in vivo investigations. J. Inorg. Biochem. 2005, 99, 627-636. [CrossRef]

12. Nollet, L.; van der Klis, J.D.; Lensing, M.; Spring, P. The Effect of Replacing Inorganic with Organic Trace Minerals in Broiler Diets on Productive Performance and Mineral Excretion. J. Appl. Poult. Res. 2007, 16, 592-597. [CrossRef]

13. Yiannikouris, A.; Connolly, C.; Power, R.; Lobinski, R. Characterization of metal-peptide complexes in feed supplements of essential trace elements. Metallomics 2009, 1, 235-248. [CrossRef] [PubMed] 
14. Radcliffe, J.S.; Aldridge, B.E.; Saddoris, K.L. Understanding Organic Mineral Uptake Mechanisms: Experiments with Bioplex Cu. 2007. Available online: www.engormix.com (accessed on 14 November 2020).

15. AAFCO. Official Publication; Association of American Feed Control Officials: Champaign, IL, USA, 2000.

16. Byrne, L.A. Analytical Assessment of Peptide-Metal Interactions and Subsequent Stability. Ph.D. Thesis, National University of Ireland, Maynooth, Ireland, 2010.

17. AOAC. Metals and Other Elements in Plants and Pet Foods: Inductively Coupled Plasma Spectroscopic Method, AOAC Official Method 985.01; AOAC International: Arlington, VA, USA, 2003.

18. Spackman, D.H.; Stein, W.H.; Moore, S. Automatic Recording Apparatus for Use in Chromatography of Amino Acids. Anal. Chem. 1958, 30, 1190-1206. [CrossRef]

19. Tedeschi, C.; Clement, V.; Rouvet, M.; Valles-Pamies, B. Dissolution tests as a tool for predicting bioaccessibility of nutrients during digestion. Food Hydrocoll. 2009, 23, 1228-1235. [CrossRef]

20. Amigo, L.; Hernández-Ledesma, B. Current evidence on the bioavailability of food bioactive peptides. Molecules 2020, $25,4479$. [CrossRef] [PubMed]

21. Miles, R.D.; Henry, P.R. Relative trace mineral bioavailability. Ciênc. Anim. Bras. 2000, 1, 73-93.

22. Ao, T.; Pierce, J. The replacement of inorganic mineral salts with mineral proteinates in poultry diets. World's Poult. Sci. J. 2013, 69, 5-16. [CrossRef]

23. Sun, N.; Cui, P.; Jin, Z.; Wu, H.; Wang, Y.; Lin, S. Contributions of molecular size, charge distribution, and specific amino acids to the iron-binding capacity of sea cucumber (Stichopus japonicus) ovum hydrolysates. Food Chem. 2017, 230, 627-636. [CrossRef]

24. Caetano-Silva, M.E.; Netto, F.M.; Bertoldo-Pacheco, M.T.; Alegría, A.; Cilla, A. Peptide-metal complexes: Obtention and role in increasing bioavailability and decreasing the pro-oxidant effect of minerals. Crit. Rev. Food Sci. Nutr. 2020, 61, 1470-1489. [CrossRef]

25. Sun, X.; Sarteshnizi, R.A.; Boachie, R.T.; Okagu, O.D.; Abioye, R.O.; Neves, R.P.; Ohanenye, I.C.; Udenigwe, C.C. Peptide-Mineral Complexes: Understanding Their Chemical Interactions, Bioavailability, and Potential Application in Mitigating Micronutrient Deficiency. Foods 2020, 9, 1402. [CrossRef]

26. Hrckova, M.; Rusnakova, M.; Zemanovic, J. Enzymatic hydrolysis of defatted soy flour by three different proteases and their effect on the functional properties of resulting protein hydrolysates. Czech J. Food Sci. 2002, 20, 7-14. [CrossRef]

27. Meinlschmidt, P.; Sussmann, D.; Schweiggert-Weisz, U.; Eisner, P. Enzymatic treatment of soy protein isolates: Effects on the potential allergenicity, technofunctionality, and sensory properties. Food Sci. Nutr. 2015, 4, 11-23. [CrossRef] [PubMed]

28. Grzonka, Z.; Kasprzykowski, F.; Wiczk, W. Cysteine Proteases. In Industrial Enzymes: Structure, Function and Applications; Springer: Cham, Switzerland, 2007; pp. 181-195.

29. Auld, D.S. Metalloproteases. In Encyclopedia of Biological Chemistry, 2nd ed.; Lennarz, W.J., Lane, M.D., Eds.; Academic Press: Waltham, MA, USA, 2013; pp. 86-89.

30. Mamo, J.; Assefa, F. The Role of Microbial Aspartic Protease Enzyme in Food and Beverage Industries. J. Food Qual. 2018, 2018, 7957269. [CrossRef]

31. Hedstrom, L. Serine Protease Mechanism and Specificity. Chem. Rev. 2002, 102, 4501-4524. [CrossRef] [PubMed]

32. Barth, A. Infrared spectroscopy of proteins. Biochim. Biophys. Acta (BBA) Bioenerg. 2007, 1767, 1073-1101. [CrossRef] [PubMed]

33. Cantwell, C.; Byrne, L.A.; Connolly, C.D.; Hynes, M.J.; McArdle, P.; Murphy, R.A. Quantitative assessment of copper proteinates used as animal feed additives using ATR-FTIR spectroscopy and powder X-ray diffraction (PXRD) analysis. Food Addit. Contam. Part A 2017, 34, 1344-1352. [CrossRef]

34. Rubino, J.T.; Chenkin, M.P.; Keller, M.; Riggs-Gelasco, P.; Franz, K.J. A comparison of methionine, histidine and cysteine in copper(i)-binding peptides reveals differences relevant to copper uptake by organisms in diverse environments. Metallomics 2011, 3, 61-73. [CrossRef]

35. Martell, A.E.; Smith, R.M. Amino Acids. In Critical Stability Constants; Plenum Press: New York, NY, USA, $1974 ;$ Volume 1.

36. Paksi, Z.; Jancsó, A.; Pacello, F.; Nagy, N.; Battistoni, A.; Gajda, T. Copper and zinc binding properties of the N-terminal histidine-rich sequence of Haemophilus ducreyi Cu, Zn superoxide dismutase. J. Inorg. Biochem. 2008, 102, 1700-1710. [CrossRef]

37. Gonzalez, P.; Bossak-Ahmad, K.; Vileno, B.; Wezynfeld, N.E.; El Khoury, Y.; Hellwig, P.; Hureau, C.; Bal, W.; Faller, P. Triggering $\mathrm{Cu}$-coordination change in $\mathrm{Cu}$ (ii)-Ala-His-His by external ligands. Chem. Commun. 2019, 55, 8110-8113. [CrossRef]

38. Mena, S.; Mirats, A.; Caballero, A.B.; Guirado, G.; Barrios, L.A.; Teat, S.J.; Rodriguez-Santiago, L.; Sodupe, M.; Gamez, P. Drastic Effect of the Peptide Sequence on the Copper-Binding Properties of Tripeptides and the Electrochemical Behaviour of Their Copper (II) Complexes. Chem. Eur. J. 2018, 24, 5153-5162. [CrossRef]

39. Wu, Z.; Fernandez-Lima, F.A.; Russell, D.H. Amino acid influence on copper binding to peptides: Cysteine versus arginine. J. Am. Soc. Mass Spectrom. 2010, 21, 522-533. [CrossRef]

40. Torres-Fuentes, C.; Alaiz, M.; Vioque, J. Affinity purification and characterisation of chelating peptides from chickpea protein hydrolysates. Food Chem. 2011, 129, 485-490. [CrossRef]

41. Carlton, D.D.; Schug, K.A. A review on the interrogation of peptide-metal interactions using electrospray ionization-mass spectrometry. Anal. Chim. Acta 2011, 686, 19-39. [CrossRef]

42. Smith, R.M.; Martell, A.E.; Motekaitis, R.J. (Eds.) NIST Critically Selected Stability Constants of Metal Complexes Database; Standard Reference Data Program; National Institute of Standards and Technology, U.S. Deptartment of Commerce: Gaithersburg, MD, USA, 2004. 
43. Byrne, L.A.; Hynes, M.J.; Connolly, C.D.; Murphy, R.A. Analytical determination of apparent stability constants using a copper ion selective electrode. J. Inorg. Biochem. 2011, 105, 1656-1661. [CrossRef]

44. Kozlowski, H.; Kowalik-Jankowska, T.; Jezowska-Bojczuk, M. Chemical and biological aspects of $\mathrm{Cu}^{2+}$ interactions with peptides and aminoglycosides. Coord. Chem. Rev. 2005, 249, 2323-2334. [CrossRef]

45. Casolaro, M.; Chelli, M.; Ginanneschi, M.; Laschi, F.; Muniz-Miranda, M.; Papini, A.M.; Sbrana, G. Spectroscopic and potentiometric study of copper(II) complexes with -histidyl-glycyl-histidyl-glycine in aqueous solution. Spectrochim. Acta A Mol. Biomol. Spectrosc. 1999, 55, 1675-1689. [CrossRef]

46. Kozlowski, H.; Bal, W.; Dyba, M.; Kowalik-Jankowska, T. Specific structure-stability relations in metallopeptides. Coord. Chem. Rev. 1999, 184, 319-346. [CrossRef]

47. Matera, A.; Brasuń, J.; Cebrat, M.; Światek-Kozłowska, J. The role of the histidine residue in the coordination abilities of peptides with a multi-histidine sequence towards copper(II) ions. Polyhedron 2008, 27, 1539-1555. [CrossRef]

48. Guo, R.; Henry, P.R.; Holwerda, R.A.; Cao, J.; Littell, R.C.; Miles, R.D.; Ammerman, C.B. Chemical characteristics and relative bioavailability of supplemental organic copper sources for poultry. J. Anim. Sci. 2001, 79, 1132-1141. [CrossRef] [PubMed] 